IZA DP No. 9881

Smoking Behaviour and Early Retirement Due to Chronic Disability

Tommy Bengtsson

Anton Nilsson

April 2016 


\title{
Smoking Behaviour and Early Retirement Due to Chronic Disability
}

\author{
Tommy Bengtsson \\ Lund University \\ and IZA
}

\author{
Anton Nilsson \\ Aarhus University \\ and Lund University
}

\section{Discussion Paper No. 9881 \\ April 2016}

IZA
P.O. Box 7240
53072 Bonn
Germany

\author{
Phone: +49-228-3894-0 \\ Fax: +49-228-3894-180 \\ E-mail: iza@iza.org
}

\begin{abstract}
Any opinions expressed here are those of the author(s) and not those of IZA. Research published in this series may include views on policy, but the institute itself takes no institutional policy positions. The IZA research network is committed to the IZA Guiding Principles of Research Integrity.

The Institute for the Study of Labor (IZA) in Bonn is a local and virtual international research center and a place of communication between science, politics and business. IZA is an independent nonprofit organization supported by Deutsche Post Foundation. The center is associated with the University of Bonn and offers a stimulating research environment through its international network, workshops and conferences, data service, project support, research visits and doctoral program. IZA engages in (i) original and internationally competitive research in all fields of labor economics, (ii) development of policy concepts, and (iii) dissemination of research results and concepts to the interested public.
\end{abstract}

IZA Discussion Papers often represent preliminary work and are circulated to encourage discussion. Citation of such a paper should account for its provisional character. A revised version may be available directly from the author. 


\section{ABSTRACT \\ Smoking Behaviour and Early Retirement Due to Chronic Disability*}

This paper considers the long-term effects of smoking on disability retirement. Exploiting population-wide registry data from Sweden, we contribute to the literature by accounting for a much broader range of potential confounders. In particular, by the use of sibling and twin fixed effects, we account for all unobserved heterogeneity in childhood environment and family characteristics. Moreover, we are able to control for detailed information on socioeconomic status, marital status and health. We also contribute by comparing effects on different diagnoses for which disability pension was granted, thus shedding some light on the biological mechanisms linking smoking to disability retirement. We demonstrate a strong association between smoking and disability retirement. Among individuals aged 50-64, smokers have a six percentage point higher probability of receiving (full) disability pension. However, while the relationship remains significant when accounting for confounders such as family environment, the size of the effect is much attenuated. Effects are concentrated to mental and musculoskeletal conditions, but effects on neoplasms, nervous system, eye and circulatory diagnoses are also found. The results are largely driven by health problems severe enough to merit hospitalization, and there is no evidence of a role played by financial incentives.

JEL Classification: $\quad 112, \mathrm{~J} 26$

Keywords: smoking, disability retirement, specific conditions, siblings, twins

Corresponding author:

Anton Nilsson

Department of Economics and Business Economics

Aarhus University

Fuglesangs Allé 4

DK-8210 Aarhus $V$

Denmark

E-mail: anilsson@econ.au.dk

\footnotetext{
* The authors thank Christopher $\mathrm{J}$ Gerry, Petter Lundborg and seminar participants at Aarhus University, Lund University and at the Health Economists' Study Group Meeting in Manchester for valuable comments and suggestions. Research grants from the Centre for Economic Demography and from the Jan Wallander and Tom Hedelius Foundation are gratefully acknowledged.
} 


\section{INTRODUCTION}

Smoking is strongly associated with worse health and labour market outcomes. The effects on morbidity and mortality are particularly well-recognised, and smoking is often referred to as “the leading preventable cause of premature disease and death" in developed countries (e.g. USDHHS 2014). Compared to pure health outcomes, evidence on labour market outcomes, such as the ability to stay in the labour force in old ages, is more sparse. As populations grow older and policy-makers seek to consolidate public finances by making people stay in the labour force longer, a precise understanding of the effects of smoking on work ability becomes crucial. This study contributes to the understanding of this issue by estimating smoking's effects on disability retirement.

The medical literature has in particular provided strong evidence that smoking increases the risk of cancer (Gandini et al. 2008), respiratory diseases (Jayes et al. 2014), and cardiovascular diseases (Mons et al. 2015). Mortality from these conditions is drastically higher among smokers, and active smokers die about 10 years earlier than non-smokers do (Doll et al. 2004; Prabhat, Landsman and Anderson 2013). Effects on diseases such as diabetes (Chielero et al. 2008), various musculoskeletal conditions (Murray 2014) and mental conditions (Johnson et al. 2000; Banham and Gilbody 2010), have been documented as well.

Associations between smoking and income, sick-leaves or disability pension have been estimated by a rather small number of studies. In the U.S., current smokers have been found to earn 1-8 percent less than non-smokers (Leigh and Berger 1989; Levine, Gustafson and Velenchik 1997). In Canada, they earned 8 percent less (Auld 2005) and in the Netherlands 10 percent less (van Ours 2004), although in the latter study this effect was confined to men only. Smokers also have lower life-time income than others (Böckerman, Hyytinen and Kaprio 2015). Finally, they are more likely to be on sick-leave (Lundborg 2007; Skillgate et al 2009) and to receive disability pension (e.g. Eriksen et al. 1998; Husemoen et al. 2004; Haukenes et al 2013; Lalluka et al. 2015).

Because of small data sets and limited availability of control variables, almost all studies on the effects of smoking on disability pension have been unable to distinguish between smoking and confounders such as childhood environment and family background. The failure to account for family background is potentially worrisome, as smoking is related to factors such as the absence of one or two parents during upbringing, parental smoking, and other unobserved factors that are shared between siblings (Isohanni, Moilanen and Rantakallio 1991; Gilman et al. 2008; Baska et al. 2010; Melchior 2010). If factors like these are also related to productivity or to the propensity to work, this will bias the estimated effect of smoking unless sibling or even 
twin comparisons are made. A series of papers based on Finnish twins (Koskenvuo et al. 2011; Ropponen et al. 2013; Korhonen et al. 2015) have considered smoking's effect on disability retirement. However, as the analysis was confined to twins only, sample sizes were rather small and, with the exception of Korhonen et al. (2015), these studies only considered disability retirement due to particular diseases.

In contrast to previous studies on smoking and disability retirement, we are able to exploit a comprehensive population sample. This also allows us to extensively account for confounders. In particular, family background is accounted for by comparing outcomes of siblings but also twins. Whereas the latter has the advantage that we may be able to more fully account for genetic and environmental factors, the former enables us to exploit a much larger and likely more representative sample. Our analysis focuses on siblings and we view the results based on twins more as a sensitivity check.

We exploit information from the Swedish Medical Birth Register, which records smoking habits among all women who have given birth since 1983; these data are then linked to a number of national registers. As an additional contribution, we contrast the effects on disability retirement due to different types of diagnoses. Disability retirement is observed on average two decades after the smoking information is recorded, implying that our focus is on the long-term effects of mid-life smoking. ${ }^{1}$

We find a strong correlation between smoking and disability retirement. However, our results suggest that much of the relationship is due to confounders such as family background. In particular, almost half of the effect disappears when sibling fixed effects are controlled for. Our results can be partly explained by health problems severe enough to merit hospitalization, and there is no evidence that smokers enter disability retirement because of their lower labour incomes.

\section{METHODS}

\subsection{Data}

We use the Swedish Interdisciplinary Panel (SIP), administered by the Centre for Economic Demography, Lund University, Sweden. The database is obtained from Statistics Sweden (Statistiska centralbyrån) and comprises several national registers covering the entire Swedish

\footnotetext{
${ }^{1}$ In contrast to several studies based on survey data, we are unable to account for lifestyle factors such as alcohol consumption and physical exercise. However, previous evidence (Korhonen et al. 2007; Haukenes et al. 2013; Ropponen et al. 2013; Korhonen et al. 2015) suggests that accounting for these variables makes only a small difference.
} 
population. These include the Medical Birth Register, the Tax Register, the Education Register, the Patient Register, and a register with information on disability pension spells from the National Agency for Social Insurance (Försäkringskassan). Siblings are identified as having the same biological mother and twins are identified as being siblings with the same month of birth.

Information on smoking status is obtained from the Birth Register. From 1983 and onwards, at her first visit to antenatal care, every pregnant woman was asked whether she smokes at least one cigarette per day. ${ }^{2}$ The individual was also asked whether she smoked 10 or more cigarettes per day. Our main analysis employs an indicator for smoker which takes the value of one if the individual smoked at least one cigarette per day during at least one pregnancy; we also create an indicator for heavy smoker, taking the value of one if the individual smoked at least 10 cigarettes per day during at least one pregnancy. Needless to say, some women might temporarily quit smoking when becoming pregnant, and our estimates will capture effects among individuals who are somewhat more dependent or less aware of the consequences of smoking. In addition to smoking, the register contains information on maternal height and weight at the first visit to antenatal care.

We define disability retirement as the uptake of full disability pension during the entire year, and focus on the year 2011 in our analysis. Full disability pension is granted to individuals who are below the age of 65 and who are deemed incapable of ever doing work, due to illness, injury or other disability. There is also information on the diagnosis underlying the disability pension. We create groups of diagnoses based on "chapters" according to the ICD-10 classification, provided by the World Health Organization. 16 groups of diagnoses are available: infectious and parasitic diseases; neoplasms; conditions of blood and blood forming organs; endocrine, nutritional and metabolic diseases; mental and behavioural disorders; diseases of the nervous system; diseases of the eye and adnexa; diseases of the ear and mastoid process, diseases of the circulatory system; diseases of the respiratory system; diseases of the digestive system; diseases of skin and subcutaneous tissue; diseases of the musculoskeletal system and connective tissue; diseases of the genitourinary system; congenital anomalies; and injuries and poisonings. ${ }^{3}$

Our analysis is based on the population of native Swedish women born between 1947 and

\footnotetext{
${ }^{2}$ The first visit to antenatal care normally takes place between week 8 and 12 of the pregnancy.

${ }^{3}$ Despite the requirement that the individual must be deemed incapable of ever doing work, disability pensions are sometimes terminated. Moreover, up to year 2008 the eligibility rules were less tight and individuals could receive temporary disability pension. As rules were tightened, there was a relatively large outflow from disability retirement between 2008 and 2010. We focus on the year 2011 because this is the most recent year for which we have data, and because disability retirement in earlier years may not represent chronic disability.
} 
1961 (thus aged 50-64 in 2011), who gave birth to at least one child between the years 1983 and 2011. Excluding those not alive in 2011 (2 percent), those with missing information on smoking at all their pregnancies (3 percent) and those with missing information on education (0.04 percent), our full sample contains 317,277 individuals. Of these individuals, there are 83,295 for which at least one sister is also in the full sample; we refer to these as belonging to the "sibling sample". Moreover, there are 2,312 twins for which their co-twin is also in the full sample; we refer to these as belonging to the "twin sample".

Table I provides means and standard deviations of relevant variables in our three samples. As it turns out, the samples are all quite similar in characteristics. Individuals are on average born in 1956-1957, and smoking is on average observed in 1988. About 28 percent of all individuals are smokers. ${ }^{4}$

\section{< Table I about here >}

\subsection{Econometric method}

Much of our analysis will be using sibling fixed effects, meaning that we compare smoking and disability pension between siblings. In addition, we will compare outcomes of twins, thus further accounting for differences in environments and genetic factors. While the use of twins requires us to use a smaller sample and raises some issues of external validity, it is interesting to see if the results are much different from those obtained when comparing siblings.

For computational tractability and in order to be able to interpret effects in percentage points, we run linear probability models, where the outcome variable is an indicator taking the value of one if the individual obtains full disability pension in 2011 (in most models, due to any condition). The regression equation takes the following form.

$$
D P_{i j}=\alpha+\beta \text { Smoker }_{i j}+X_{i j} \gamma+f_{j}+\varepsilon_{i j}
$$

Here, $i$ is an index for the individual and $j$ for the mother or the twin pair. ${ }^{5} X$ contains one

\footnotetext{
${ }^{4}$ Responses to surveys distributed by Statistics Sweden suggest that among the general population of women aged 25-44, smoking prevalence was 34 percent in 1988 (Danielsson, Gillian and Hemström 2009), a number that is somewhat higher than ours is. Midlöv et al. (2014) suggest that 33 percent of individuals in (roughly) our cohorts smoked in 1988/89. Due to quitting, this number had then reduced to 21 percent in 2004/05.

${ }^{5}$ Note that "mother" refers to the mother of the mother observed in the Medical Birth Register, as the person of interest is the woman with smoking records in the birth register. Our analysis uses biological mothers, but replacing them with adoptive mothers or dropping individuals that were adopted makes essentially no difference the the results.
} 
or several control variables; in our most simple models we use dummies to control for birth year, family size and birth order of the individual, parents' years of education and the number of times the individual has been asked whether she smokes (apart from missing values, this is the number of children of the individual of interest). We then add controls for mother (or twin pair) fixed effects. More extensive models also include fixed effects for the individual's years of attained education, occupation, and marital status. Income and adult health are likely to be endogenous to smoking, but we further run models accounting for these, in order to explore mechanisms. Standard errors are clustered at the family (i.e. mother) level.

\section{RESULTS}

\subsection{OLS on different samples}

We begin our analysis by running models without sibling or twin fixed effects. Table II shows the results, where we first run the analysis on the full sample, the sibling sample and the twin sample. We find that siblings and twins are representative in the sense that the associations between smoking and disability pension are similar across the three samples. The estimates based on the full sample and the sibling sample are even identical up to four decimal points, and suggest that smokers face a 5.64 percentage point higher probability of receiving disability pension.

\section{< Table II about here >}

We also run these regressions on two subsamples of the siblings and twins samples. In particular, since only families (or twins) where there is a variation in smoking behaviour are going to contribute to the forthcoming fixed effects estimates, it is of interest to separately consider those for which these is a variation in smoking - and those for which there is not. When considering families for which there is no variation, the smoking dummy simply becomes an indicator for coming from a family where every girl ends up smoking, rather than coming from a family where no girl ends up smoking. Indeed, the estimated effect of this indicator may capture many aspects of family quality as well. ${ }^{6}$

Restricting attention to siblings that do not differ in terms of smoking, we find an effect of

${ }^{6}$ Taking father's years of education as one indicator of family quality, we find that in families where no daughter becomes a smoker, fathers on average have 10.05 years of education, whereas in families where all daughters become smokers, they only have 8.91. In families where we observe a variation in daughters' smoking behaviour, fathers' average years of education is 9.31 . 
0.0745, almost two percentage points higher than the effect in the overall sample. Considering the complement subsample of siblings differing in smoking, we find an effect that is instead two percentage points (or more than a third) lower than the one in the overall sample, attaining a value of 0.0365 . The estimate based on twins not differing in smoking is also higher than the one based on twins differing in smoking, but the difference is less pronounced.

\subsection{Main results}

We then turn to our main results, using sibling or twin fixed effects. Results are shown in panel A of Table III. We find that adding sibling fixed effects reduces the estimate by almost a half, to 3.33 percentage points (see column A). This estimate, however, is not much lower than the OLS estimate based on siblings with different smoking behaviours, suggesting that in these “intermediate quality families", confounding family characteristics are not very relevant.

\section{< Table III about here >}

In Model B, we add controls for educational attainment, occupation, and marital status. This reduces the estimate by another 50 percent, to 0.0171 . While this effect is relatively modest, it is still highly significant, and one should note that it is potentially an underestimate of the net effect of smoking, since all the added controls may simply be mediators in the relationship between smoking and retirement due to disability. ${ }^{7}$

Models C and D show our fixed effects results based on the twin sample. These results are less precise than the ones obtained using the sibling sample, and they cannot statistically be distinguished. The estimate in Model C (where further controls have not been added) is virtually the same as the one based on OLS, and adding further controls reduces the estimate somewhat.

In panel B, we consider effects in different age spans, by interacting smoking with three different age indicators: 50-54, 55-59 and 60-64. The effect on disability retirement becomes substantially stronger, the higher the age. At age 50-54, a smoking sibling has a 2.21 percentage point higher probability of being on disability pension when not accounting for confounders; the effect increases to 3.85 percentage points at age 55-59 and to 6.58 percentage points at age 60-64. Adding controls makes the effects diminish similarly to before.

\footnotetext{
${ }^{7}$ If the result of model D represents the causal effect of smoking, these results suggest that 8 percent of all instances of disability retirement could be eliminated by turning smokers into non-smokers. Furthermore, assuming that the effect extends to all individuals aged 50-64 and assuming that these can produce the average GDP per worker in Sweden, production in Sweden could increase by about 7 billion SEK (1 billion USD) per year by turning smokers into non-smokers.
} 


\subsection{Quitting and intensity of smoking}

While we are not able to follow individuals' smoking behaviour for a long period of time, we can examine some effects of smoking cessation by considering women who have given birth more than once, and were thus asked about their smoking habits multiple times. We create indicators for "always smokers", taking the value of one if the mother was a smoker at the beginning of all her pregnancies, and for "quitters", taking the value of one if the mother was a smoker up to a given pregnancy and then was a non-smoker at all pregnancies thereafter. Few individuals initiate smoking or switch back and forth between being a smoker and a non-smoker between pregnancies, and we exclude these from the analysis.

In panel A of Table IV, we show results when re-running our main analysis using the two indicators. According to all of our models, the coefficient for quitters is very close to zero and it is statistically insignificant. Women quitting smoking in middle age do not appear to face a higher probability of disability retirement.

\section{< Table IV about here >}

In panel B of Table IV, we then examine whether heavy smoking (smoking at least 10 cigarettes per day) has an additional effect. In a sibling fixed effects model with no further controls, the baseline effect of smoking is 2.80 percentage points, and being a heavy smoker adds another 1.43 percentage points. However, when adding further controls, the additional effect of heavy smoking becomes much less pronounced and statistically insignificant.

\subsection{Medical reason for retirement}

In Table V, we consider disability pension due to different conditions. The analysis thus explores effects health insults that may result from smoking, where severity is measured in terms of the increased probability of work limitation. In order to keep precision high, we here, as well as in the forthcoming sections, focus on siblings only.

\section{< Table V about here >}

In models accounting for sibling fixed effects but no further controls, we find that at the 10 percent level of significance, 6 types of conditions are affected by smoking. In line with the observation that smoking reduces life expectancy due to neoplasms and circulatory conditions, we find that smokers are more likely to withdraw from the labour market due to these. However, 
the estimated effects are small, in absolute terms. The probability of disability pension due to neoplasms is only elevated by 0.0006 and the probability of disability retirement due to circulatory conditions is only elevated by 0.0021 . Interestingly, no effect on respiratory problems is obtained.

Most of the effect on disability retirement is accounted for by mental and musculoskeletal conditions, with coefficients of 0.0150 and 0.0089 , respectively. This is not entirely surprising as these are also the two most common types diagnoses for which individuals obtain disability pension. However, the effect on mental diagnoses is proportionally large and corresponds to 45 percent of the overall effect of smoking. Finally, we also obtain effects on disability retirement due to conditions of the nervous system and eye conditions, but these effects are rather small and only significant at the 10 percent level.

As when estimating the overall effect on disability pension, we find that further controlling for socioeconomic and marital status reduces the estimates. Effects on disability retirement due to problems with the nervous system and eyes are now no longer statistically significant at conventional levels. For the other diagnoses that where significant effects were previously found, estimates reduce by about half on average. ${ }^{8}$

\subsection{Accounting for health}

In this section, we explore the relationship between smoking and two more objective measures of health. The analysis serves two different purposes. First, we wish to determine whether unhealthy individuals select into smoking. If this is the case, our results may be driven by omitted health variables. Second, we are interested in whether our results to some extent can be explained by measures of objective health close to the outcome year. If not, we would worry that results instead reflect some unobserved characteristics of smokers, such as a higher disutility from work.

In the first column of Table VI, we examine whether smoking is related to height, within siblings. ${ }^{9}$ Height is a commonly used measure of overall health during childhood (Elo and Preston 1992) and is as such unlikely to be influenced by smoking itself. We find no evidence of a relationship between height and smoking, suggesting that selection into smoking among unhealthy individuals may not be an issue. ${ }^{10}$

\footnotetext{
8 The table also shows sample averages of disability pension due to different conditions, allowing us to calculate relative effects of smoking. By far, the largest relative effects are obtained for circulatory conditions; smoking is found to increase the probability of disability retirement due to circulatory conditions by around 200 percent. The second largest relative effects are obtained for neoplasms (more decimals used for exact calculation).

${ }^{9}$ Height is measured in centimeters and averaged over pregnancies.

${ }^{10}$ Further information in the Birth Register includes the woman's pre-pregnancy weight and her newborn’s
} 


\section{$<$ Table VI about here >}

We are then interested in health measures that are observed later and that we may think of as mediators of the smoking-disability retirement relationship. We here use inpatient visits between 2001 and 2011. The second column of Table VI shows results from regressions of hospitalization (at least one hospital day between 2001 and 2011) against smoking. We find that smoking has a significant effect on the probability of hospitalization; with an estimate of 0.0309 or 0.0211 , depending on whether further controls are added.

Given the significant relationship between smoking and hospitalization, we move on and add controls for hospitalizations to our main models. For completeness, we create controls for hospitalization due to each and every type of health problem (according to the ICD chapters), and we create not only indicators for at least one day, but also for the total number of days and for the total number of days squared. We find that estimates fall by almost 30 percent when adding indicators for at least one hospital day due to various health problems. Further adding linear and quadratic controls for the number of hospital days to due to various diagnoses makes only a small difference. The results suggest that a substantial share of smoking's effect on disability retirement can be explained by health problems severe enough to merit hospitalization, although the majority of the effect is still unexplained.

\subsection{Accounting for economic status}

Rather than through work disability, the effect of smoking may operate through discrimination or a lower productivity before entering disability retirement. If these factors are at play, working may be less attractive and individuals may try to obtain disability pension by exaggerating health problems. ${ }^{11}$ We limit the sample to individuals not on disability pension in 2001, because we want to be able to measure financial variables at a time before individuals entered disability retirement.

In Table VII, we explore the relevance of these hypothesises. In a model without further controls, we find that smokers earn about 8,000 SEK less per year, corresponding to 4 percent

weight. We find that a smoking mother has significantly lower body mass index (weight divided by height squared) and gives birth to significantly lighter children. The interpretation of these results is complicated, however, as they may reflect both causal effects of smoking and selection into smoking (Chiolero et al. 2008; Fertig 2010). In any case, controlling for these variables in our main regressions makes little difference to our results.

11 The presence of a minimum and maximum disability pension is one reason why those with lower incomes may be more prone to enter disability retirement. Other potential reasons include emotional costs due to discrimination and a lower motivation for work among less productive individuals. 
of an average income. The effect is much lower when controlling for further variables. We also look at spousal income and family net wealth. Partly because of a lower probability of marrying, we find large negative effects of smoking on these variables, also in models with further controls.

\section{< Table VII about here >}

Since the relationships between smoking and financial variables turned out significant, we then move on to control for these in our main regressions. Without the financial controls, the effect of smoking on disability retirement is in this sample 0.014 or 0.010 , depending on the specification. Adding the controls for financial variables reduces the estimates only slightly, to 0.013 and 0.009 , suggesting that financial variables are not important in explaining our overall results.

\section{DISCUSSION}

Using a population-wide dataset and controlling for a broad range of potential confounders, this study estimated the long-run effects of midlife smoking on disability retirement. While raw correlations suggest smoking to be a major determinant of the uptake of disability pension, our estimates based on sibling comparisons suggest dramatically smaller, yet significant, effects. The differences between OLS results and sibling fixed effects results are largely driven by families where every individual shares the same smoking behaviour., pointing at the importance of unobserved characteristics only in these families.

Effects are concentrated to mental and musculoskeletal problems (the most common causes for disability retirement), but effects on neoplasms and on circulatory conditions are found as well. Our results indicate that the aspects of health that are the most affected by smoking may be quite different when work disability is considered, compared to mortality or other pure health outcomes. A substantial part of our relationships can be explained by health problems severe enough to merit hospitalization, but there is no evidence of any role played by incentives or financial circumstances.

To grasp the benefits from reducing or abolishing smoking, individuals and policy-makers are in need for knowledge about the long-term labour market consequences of smoking. This paper has provided one piece of such evidence - showing that abolishing smoking would likely enable individuals to stay longer in the labour force instead of entering disability retirement. 
Disability retirement, however, may only represent "the top of the iceberg" of the disutility from work experienced by individuals in poor health. The benefits to workers from giving up smoking are thus likely to be higher than what is immediately implied by this paper. 


\section{REFERENCES}

Auld MC. 2005. “Smoking, drinking, and income.” Journal of Human Resources 40: 505-518.

Banham L, Gilbody S. 2010. "Smoking cessation in severe mental illness: what works?” Addiction 105: 11761189.

Baska T, Warren CW, Hudeckova H, Ochaba R, Stastny P, Lea V, Lee J. 2010. ”The role of family background on cigarette smoking among adolescent school children in Slovakia: findings from the 2007 Slovakia global youth tobacco survey.” International Journal of Public Health 55: 591-597.

Böckerman P, Hyytinen A, Kaprio J. 2015. ”Smoking and long-term labour market outcomes.” Tobacco Control 24: $348-353$.

Chielero A, Faeh D, Paccaud F, Cornuz J. 2008. "Consequences of smoking for body weight, body fat distribution, and insulin resistance.” American Journal of Clinical Nutrition 87: 801-809.

Danielsson M, Gilliam H, Hemström Ö. 2009. “Tobaksvanor och tobaksrelaterade besvär.” In: Folkhälsorapport 2009. Stockholm: Socialstyrelsen.

Doll R, Peto R, Boreham J, Sutherland I. 2004. “Mortality in relation to smoking: 50 years' observations on male British doctors.” British Medical Journal 309: 901-911.

Elo IT, Preston SH. 1992. "Effects of Early-Life Conditions on Adult Mortality: A Review.” Population Index 58: 186-212.

Eriksen W, Natvig B, Rutle O, Bruusgaard. 1998. "Smoking as a predictor of long-term work disability in physically active and inactive people.” Occupational Medicine 48: 315-320.

Fertig A. 2010. "Selection and the effect of prenatal smoking.” Health Economics 19: 209-226.

Gandini S, Botteri E, Iodice S, Boniol M, Lowenfels AB, Maisoneuve P, Boyle P. 2008. “Tobacco smoking and cancer: a meta-analysis.” International Journal of Cancer 122: 155-164.

Gilman SE, Martin LT, Abrams DB, Kawachi I, Kubzansky L, Loucks EB, Rende R, Rudd R, Buka SL. 2008. "Educational attainment and cigarette smoking: a causal association?" International Journal of Epidemiology 37: 615-624.

Haukenes I, Riise T, Haug K, Farbu E, Maeland JG. 2013.”Smokers’ increased risk for disability pension: social confounding or health-mediated effects? Gender-specific analysis of the Hordaland Health Study Cohort.” Journal of Epidemiology and Community Health 67: 758-764.

Husemoen LLN, Osler M, Godtfredsen NS, Prescott E. 2004. "Smoking and subsequent risk of early retirement due to chronic disability.” European Journal of Public Health 14: 86-92.

Isohanni M, Moilanen I, Rantakallio P. 1991. ”Determinants of teenage smoking, with special reference to nonstandard family background." British Journal of Addiction 86: 391-398.

Jayes L, Britton J, Vardavas C, Leonardi-Bee J. 2014. "Systematic reviews and meta-analyses on the effects of active and passive smoking on respiratory health outcomes: the SmokeHaz online resource.” Lancet 384: 42. 
Johnson JG, Cohen P, Pine DS, Klein DF, Kasen S, Brook JS. 2000. “Association between cigarette smoking and anxiety disorders during adolescence and early adulthood.” JAMA 284: 2348-2351.

Korhonen T, Broms U, Varjonen J, Romanov K, Koskenvuo M, Kinnunen T, Kaprio J. 2007. ”Smoking behaviour as a predictor of depression among Finnish men and women: a prospective cohort study of adult twins.” Psychological Medicine 37: 705-715.

Korhonen T, Smeds E, Silventoinen K, Heikkilä K, Kaprio J. 2015. ”Cigarette smoking and alcohol use as predictors of disability retirement: a population-based cohort study.” Drug and Alcohol Dependence 155: 260-266.

Koskenvuo K, Broms U, Korhonen T, Laitinen LA, Huunan-Seppälä A, Keistinen T, Autti-Rämö A, Kaprio J, Koskenvuo M. 2011. "Smoking strongly predicts disability retirement due to COPD: the Finnish Twin Cohort Study.” European Respiratory Journal 37: 26-31.

Lallukka T, Rahkonen O, Lahelma E, Lahti J. 2015. “Joint associations of smoking and physical activity with disability retirement: a register-linked cohort study.” BMJ Open 5: e006988.

Leigh JP, Berger M. 1989. “Effects of smoking and being overweight on current earnings.” American Journal of Preventive Medicine 5: 8-14.

Levine PB, Gustafsson TA, Velenchik AD. 1997. "More bad news for smokers? The effects of cigarette smoking on wages.” Industrial Labour Relations Review 50: 493-509.

Lundborg P. 2007. "Does smoking increase sick leave? Evidence using data on Swedish workers.” Tobacco Control 16: 114-118.

Melchior M, Chastang JF, MacKinnon, Galera C, Fornbonne E. 2010. “The intergenerational transmission of tobacco smoking - the role of parents’ long-term smoking trajectories.” Drug and Alcohol Dependence 107: 257260.

Midlöv P, Calling S, Sundquist J, Sundquist K, Johansson SE. 2014. “The longitudinal age and birth cohort trends of smoking in Sweden: a 24-year follow-up study.” International Journal of Public Health 59: 243-250.

Mons U et al. 2015. "Impact of smoking and smoking cessation on cardiovascular events and mortality among older adults: meta-analysis of individual participant data from prospective cohort studies of the CHANCES consortium.” British Medical Journal 350: h1551.

Murray R. 2014. The role of smoking in the progressive decline of the body's major systems: a report commissioned by Public Health England. London: Public Health England.

Prabhat J, Landsman V, Anderson RN. 2013. ”21st-century hazards of smoking and benefits of cessation in the United States.” New England Journal of Medicine 368: 341-350.

Ropponen A, Korhonen T, Svedberg P, Koskenvuo M, Silventoinen K, Kaprio J. 2013. ”Persistent smoking as a predictor of disability pension due to musculoskeletal diagnoses: a 23 year prospective study of Finnish twins.” Preventive Medicine 57: 889-893.

Skillgate E, Vingård E, Josephson M, Holm LW, Alfredsson L. 2009. ”Is smoking and alcohol consumption associated with long-term sick leave due to unspecific back or neck pain among employees in the public sector? Results of a three-year follow-up cohort study.” Journal of Rehabilitation Medicine 41: 550-556. 
USDHHS. 2014. The health consequences of smoking - 50 years of progress: a report of the Surgeon General. Atlanta, GA: US Department of Health and Human Services, Centers for Disease Control and Prevention, National Center for Chronic Disease Prevention and Health Promotion, Office on Smoking and Health.

van Ours JC. 2004. “A pint a day raises a man’s pay; but smoking blows that gain away.” Journal of Health Economics 23: 863-886. 


\section{Tables}

Table I: Descriptive statistics

\begin{tabular}{|c|c|c|c|}
\hline & Full sample & $\begin{array}{l}\text { Sibling } \\
\text { sample }\end{array}$ & $\begin{array}{c}\text { Twin } \\
\text { sample }\end{array}$ \\
\hline Birth year & $1956(4)$ & $1956(4)$ & $1957(3)$ \\
\hline Average year of childbirth & $1988(4)$ & $1988(4)$ & $1988(4)$ \\
\hline Aged 50-54 & 0.5016 & 0.4934 & 0.5865 \\
\hline Aged 55-59 & 0.3498 & 0.3807 & 0.3354 \\
\hline Aged 60-64 & 0.1487 & 0.1259 & 0.0770 \\
\hline Primary education & 0.1023 & 0.1071 & 0.1012 \\
\hline Secondary education & 0.4657 & 0.4582 & 0.4951 \\
\hline Tertiary education & 0.4320 & 0.4347 & 0.4035 \\
\hline \multirow[t]{2}{*}{ Father's years of education } & 9.6017 & 9.6770 & 9.5787 \\
\hline & $(3.0670)$ & (3.1817) & (3.1039) \\
\hline \multirow[t]{2}{*}{ Mother's years of education } & 9.1328 & 9.1854 & 9.2190 \\
\hline & $(2.5892)$ & $(2.6585)$ & $(2.5917)$ \\
\hline Disability retirement & 0.0616 & 0.0595 & 0.0528 \\
\hline Disability retirement if smoker & 0.1045 & 0.1029 & 0.0936 \\
\hline Disability retirement if non-smoker & 0.0447 & 0.0422 & 0.0381 \\
\hline Disability retirement if aged 50-54 & 0.0474 & 0.0477 & 0.0472 \\
\hline Disability retirement if aged 55-59 & 0.0642 & 0.0616 & 0.0553 \\
\hline Disability retirement if aged 60-64 & 0.1037 & 0.0996 & 0.084 \\
\hline Smoker & 0.2826 & 0.2850 & 0.2634 \\
\hline Always smoker & 0.2285 & 0.2283 & 0.2050 \\
\hline Quitter & 0.0369 & 0.0391 & 0.0407 \\
\hline Heavy smoker & 0.1186 & 0.1196 & 0.1056 \\
\hline \multirow[t]{2}{*}{ Height } & 166.55 & 166.48 & 165.99 \\
\hline & $(5.81)$ & $(5.84)$ & $(5.72)$ \\
\hline Hospitalized 2001-2011 (any condition) & 0.3137 & 0.3126 & 0.2849 \\
\hline \multirow[t]{2}{*}{ Inpatient days 2001-2011 (any condition) } & 3.97 & 3.96 & 4.36 \\
\hline & (22.58) & $(21.15)$ & $(27.15)$ \\
\hline \multirow[t]{2}{*}{ Average income 1997-2001 (2001 SEK) } & 188,992 & 188,871 & 184,657 \\
\hline & $(92,729)$ & $(93,184)$ & $(80,046)$ \\
\hline \multirow[t]{2}{*}{ Spousal average income 1997-2001 } & 198,279 & 195,789 & 200,162 \\
\hline & $(237,199)$ & $(232,479)$ & $(213,877)$ \\
\hline \multirow[t]{2}{*}{ Family net wealth 2001 (SEK) } & 894,024 & 823,787 & 833,165 \\
\hline & $(1,64 \mathrm{E} 07)$ & $(3,386,389)$ & $(2,542,311)$ \\
\hline Individuals & 317,277 & 83,285 & 2,312 \\
\hline
\end{tabular}


Table II: Disability retirement due to any health problem - OLS on different samples

\begin{tabular}{|c|c|c|c|c|c|c|c|}
\hline & $\begin{array}{c}\text { Full } \\
\text { sample }\end{array}$ & $\begin{array}{l}\text { Sibling } \\
\text { sample }\end{array}$ & $\begin{array}{l}\text { Twin } \\
\text { sample }\end{array}$ & $\begin{array}{c}\text { Sibling sample, } \\
\text { same }\end{array}$ & $\begin{array}{c}\text { Sibling sample, } \\
\text { different }\end{array}$ & $\begin{array}{c}\text { Twin sample, } \\
\text { same }\end{array}$ & $\begin{array}{c}\text { Twin sample, } \\
\text { different }\end{array}$ \\
\hline Smoker & $\begin{array}{c}0.0564^{* * *} \\
(0.0011)\end{array}$ & $\begin{array}{l}0.0564^{\star \star *} \\
(0.0022)\end{array}$ & $\begin{array}{c}0.0503^{\star * *} \\
(0.0127)\end{array}$ & $\begin{array}{c}0.0745^{\star * *} \\
(0.0035)\end{array}$ & $\begin{array}{c}0.0365^{\star * *} \\
(0.0031)\end{array}$ & $\begin{array}{c}0.0542^{\star * *} \\
(0.0169)\end{array}$ & $\begin{array}{l}0.0485^{\star *} \\
(0.0201)\end{array}$ \\
\hline Individuals & 317,277 & 83,295 & 2,312 & 56,617 & 26,678 & 1,806 & 506 \\
\hline
\end{tabular}

Notes: *** indicates significance at the 1 percent level, ${ }^{* *}$ significance at the 5 percent level, and $*$ significance at the 10 percent level. The outcome is an indicator for receiving full disability pension in 2011. Column A shows results for the full sample, column B for the full sibling sample, column $\mathrm{C}$ for the sibling sample where siblings are all smokers or non-smokers, column D for the sibling sample where siblings differ in whether they smoke, column E for the full twin sample, column F for the twin sample where twins are both smokers or nonsmokers, column $\mathrm{G}$ for the twin sample where twins differ in whether they smoke. All regressions control for birth year fixed effects, family size fixed effects, birth order fixed effects, fixed effects for parental years of schooling and fixed effects for the number of times the individual has been asked whether she smokes. Standard errors are clustered at the mother level. 
Table III: Disability retirement due to any health problem - sibling or twin fixed effects

$\begin{array}{llll}\text { A } & \text { B } & \text { C } & \text { D }\end{array}$

A. Overall effect on disability pension in 2011

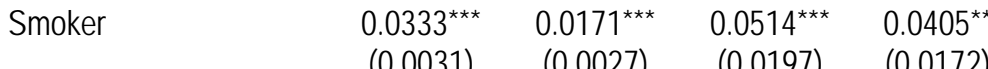

$\begin{array}{llll}(0.0031) & (0.0027) \quad(0.0197) \quad(0.0172)\end{array}$

$\begin{array}{llll}\text { Individuals } \quad 83,295 & 83,295 & 2,312 & 2,312\end{array}$

B. Effects of smoking on disability pension in 2011, among different age groups

Smoker, aged 50-54 $\quad 0.0221^{\star * *} \quad 0.0096^{\star * *} \quad 0.0171 \quad 0.0299$

$\begin{array}{lllll} & (0.0039) & (0.0035) & (0.0255) & (0.0228) \\ \text { Smoker, aged 55-59 } & 0.0385^{\star \star *} & 0.0200^{\star \star \star} & 0.0880^{\star \star} & 0.0453\end{array}$

$\begin{array}{lllll} & (0.0047) & (0.0041) & (0.0344) & (0.0303) \\ \text { Smoker, aged 60-64 } & 0.0658^{\star \star \star} & 0.0409^{\star \star \star} & 0.1447^{*} & 0.0957\end{array}$

$(0.0097) \quad(0.0084) \quad(0.0778) \quad(0.0610)$

$\begin{array}{lllll}\text { Individuals } & 83,295 & 83,295 & 2,312 & 2,312\end{array}$

Notes: *** indicates significance at the 1 percent level, ** significance at the 5 percent level, and * significance at the 10 percent level. The outcome is an indicator for receiving full disability pension in 2011. Models A-B are based on the sibling sample and Models C-D on the twin sample. In Model B and D, we add controls for level of education, type of occupation, and marital status. All regressions control for birth year fixed effects, birth order fixed effects and fixed effects for the number of times the individual has been asked whether she smokes.

Standard errors are clustered at the mother or twin pair level. 
Table IV: Stopped smoking and heavy smoking - sibling or twin fixed effects

$\begin{array}{llll}\text { A } & \text { B } & \text { C } & \text { D }\end{array}$

A. Always smokers vs quitters

$\begin{array}{lcccc}\text { Always } & 0.0379 * * & 0.0247 * * * & 0.0824^{*} & 0.0844^{*} \\ & (0.0072) & (0.0066) & (0.0427) & (0.0459) \\ \text { Quitter } & 0.0079 & 0.0015 & 0.0053 & -0.0095 \\ & (0.0074) & (0.0067) & (0.0252) & (0.0289)\end{array}$

Individuals $\quad 24,777 \quad 24,777 \quad 908 \quad 908$

B. Smokers and heavy smokers

\begin{tabular}{lcccc} 
Smoker & $0.0280^{\star * *}$ & $0.0162 * * *$ & $0.0418^{* *}$ & $0.0353^{*}$ \\
& $(0.0035)$ & $(0.0030)$ & $(0.0199)$ & $(0.0180)$ \\
Heavy smoker & $0.0143^{\star * *}$ & 0.0024 & 0.0324 & 0.0181 \\
& $(0.0054)$ & $(0.0046)$ & $(0.0367)$ & $(0.0321)$ \\
Individuals & 83,295 & 83,295 & 2,312 & 2,312 \\
\hline
\end{tabular}

Notes: *** indicates significance at the 1 percent level, $* *$ significance at the 5 percent level, and * significance at the 10 percent level. The outcome is an indicator for receiving full disability pension in 2011. Models A-B are based on the sibling sample and Models C-D on the twin sample. In Model B and D, we add controls for level of education, type of occupation, and marital status. In panel B, the effect for "Heavy smoker" represents the additional effect of smoking 10 or more cigarettes a day, over and above the effect for "Smoker". All regressions control for birth year fixed effects, birth order fixed effects and fixed effects for the number of times the individual has been asked whether she smokes. Standard errors are clustered at the mother or twin pair level. 
Table V: Disability retirement due to different diagnoses - sibling fixed effects

\begin{tabular}{|c|c|c|c|c|c|c|c|c|}
\hline & Infections & Neoplasms & Blood & Endo etc & Mental & Nervous syst & Eye & Ear \\
\hline Smoker, SFE model & $\begin{array}{c}0.0001 \\
(0.0002)\end{array}$ & $\begin{array}{l}0.0006^{\star \star} \\
(0.0003)\end{array}$ & $\begin{array}{c}0.0001 \\
(0.0001)\end{array}$ & $\begin{array}{c}0.0003 \\
(0.0005)\end{array}$ & $\begin{array}{l}0.0150^{\star \star \star} \\
(0.0019)\end{array}$ & $\begin{array}{l}0.0014^{\star} \\
(0.0007)\end{array}$ & $\begin{array}{l}0.0003^{\star} \\
(0.0002)\end{array}$ & $\begin{array}{c}0.0000 \\
(0.0002)\end{array}$ \\
\hline $\begin{array}{l}\text { Smoker, SFE model } \\
\text { with further controls }\end{array}$ & $\begin{array}{l}-0.0001 \\
(0.0002)\end{array}$ & $\begin{array}{l}0.0006^{\star \star} \\
(0.0003)\end{array}$ & $\begin{array}{c}0.0001 \\
(0.0001)\end{array}$ & $\begin{array}{c}0.0002 \\
(0.0004)\end{array}$ & $\begin{array}{l}0.0089^{\star \star \star} \\
(0.0018)\end{array}$ & $\begin{array}{c}0.0004 \\
(0.0007)\end{array}$ & $\begin{array}{c}0.0003 \\
(0.0002)\end{array}$ & $\begin{array}{l}-0.0001 \\
(0.0002)\end{array}$ \\
\hline Non-smoker mean & 0.0002 & 0.0006 & 0.0001 & 0.0007 & 0.0130 & 0.0030 & 0.0002 & 0.0003 \\
\hline & Circulatory & Respiratory & Digestive & Skin & Musculoskeletal & Urogenital & Congenital & Injury \\
\hline Smoker, SFE model & $\begin{array}{c}0.0021^{\star \star \star} \\
(0.0006)\end{array}$ & $\begin{array}{r}0.0000 \\
(0.0004)\end{array}$ & $\begin{array}{c}0.0004 \\
(0.0003)\end{array}$ & $\begin{array}{c}0.0003 \\
(0.0003)\end{array}$ & $\begin{array}{l}0.0089^{\star \star \star} \\
(0.0020)\end{array}$ & $\begin{array}{r}0.0000 \\
(0.0001)\end{array}$ & $\begin{array}{r}0.0003 \\
(0.0003)\end{array}$ & $\begin{array}{l}0.0001 \\
(0.0008)\end{array}$ \\
\hline $\begin{array}{l}\text { Smoker, SFE model } \\
\text { with further controls }\end{array}$ & $\begin{array}{c}0.0017^{\star \star \star} \\
(0.0006)\end{array}$ & $\begin{array}{l}-0.0001 \\
(0.0004)\end{array}$ & $\begin{array}{c}0.0001 \\
(0.0003)\end{array}$ & $\begin{array}{c}0.0002 \\
(0.0003)\end{array}$ & $\begin{array}{l}0.0039^{\star \star} \\
(0.0019)\end{array}$ & $\begin{array}{l}-0.0000 \\
(0.0001)\end{array}$ & $\begin{array}{c}0.0003 \\
(0.0003)\end{array}$ & $\begin{array}{l}-0.0009 \\
(0.0008)\end{array}$ \\
\hline Non-smoker mean & 0.0010 & 0.0004 & 0.0005 & 0.0003 & 0.0154 & 0.0002 & 0.0002 & 0.0028 \\
\hline
\end{tabular}

Notes: *** indicates significance at the 1 percent level, ** significance at the 5 percent level, and * significance at the 10 percent level. The outcome is an indicator for receiving full disability pension due to a certain type of diagnosis in 2011.”SFE” is shorthand for "sibling fixed effects”. In models "with further controls”, we control for level of education, type of occupation, and marital status. All regressions control for birth year fixed effects, birth order fixed effects and fixed effects for the number of times the individual has been asked whether she smokes. Standard errors are clustered at the mother level. 
Table VI: Health status

\begin{tabular}{|c|c|c|c|c|c|c|}
\hline & Height & Hospitalization & DP & $\mathrm{DP}$ & $\mathrm{DP}$ & DP \\
\hline Smoker, SFE model & $\begin{array}{c}0.0509 \\
(0.0586)\end{array}$ & $\begin{array}{c}0.0309 * * \star \\
(0.0057)\end{array}$ & $\begin{array}{c}0.0333^{\star * *} \\
(0.0031)\end{array}$ & $\begin{array}{c}0.0244^{\star * \star} \\
(0.0030)\end{array}$ & $\begin{array}{c}0.0235^{\star \star \star} \\
(0.0030)\end{array}$ & $\begin{array}{c}0.0233^{* * *} \\
(0.0029)\end{array}$ \\
\hline $\begin{array}{l}\text { Smoker, SFE model } \\
\text { with further controls }\end{array}$ & $\begin{array}{c}0.0966 \\
(0.0599)\end{array}$ & $\begin{array}{l}0.0211^{\star * *} \\
(0.0057)\end{array}$ & $\begin{array}{l}0.0171^{* * *} \\
(0.0027)\end{array}$ & $\begin{array}{l}0.0122^{\star * \star} \\
(0.0026)\end{array}$ & $\begin{array}{c}0.0116 * \star * \\
(0.0026)\end{array}$ & $\begin{array}{l}0.0116 * \star \star \\
(0.0026)\end{array}$ \\
\hline $\begin{array}{l}\text { Hospitalization } \\
\text { controls: } \\
\text { Hospitalization } \\
\text { Hospital days } \\
\text { Hospital days } \\
\text { squared }\end{array}$ & & & & $X$ & $\begin{array}{l}X \\
X\end{array}$ & $\begin{array}{l}X \\
X \\
X\end{array}$ \\
\hline Individuals & 67,053 & 83,295 & 83,295 & 83,295 & 83,295 & 83,295 \\
\hline
\end{tabular}

Notes: $* * *$ indicates significance at the 1 percent level, ** significance at the 5 percent level, and ${ }^{*}$ significance at the 10 percent level. The outcome is an indicator for receiving full disability pension in 2011.”SFE” is shorthand for "sibling fixed effects". In models "with further controls", we control for level of education, type of occupation, and marital status. All regressions control for birth year fixed effects, birth order fixed effects and fixed effects for the number of times the individual has been asked whether she smokes. Standard errors are clustered at the mother level. 
Table VII: Income (1997-2001) and wealth (2001)

\begin{tabular}{|c|c|c|c|c|c|c|}
\hline & Income & $\begin{array}{l}\text { Spousal } \\
\text { income }\end{array}$ & Family wealth & $\mathrm{DP}$ & DP & DP \\
\hline Smoker, SFE model & $\begin{array}{c}-7,958 * \star * \\
(1,018)\end{array}$ & $\begin{array}{c}-46,287^{\star \star *} \\
(2,524)\end{array}$ & $\begin{array}{c}-229,691^{\star \star *} \\
(41,442)\end{array}$ & $\begin{array}{c}0.014^{\star \star *} \\
(0.002)\end{array}$ & $\begin{array}{c}0.013^{* * *} \\
(0.002)\end{array}$ & $\begin{array}{c}0.013^{\star * *} \\
(0.002)\end{array}$ \\
\hline $\begin{array}{l}\text { Smoker, SFE model } \\
\text { with further controls }\end{array}$ & $\begin{array}{c}-1,877^{\star *} \\
(920)\end{array}$ & $\begin{array}{c}-17,648^{\star \star *} \\
(2,037)\end{array}$ & $\begin{array}{c}-122,379 * \star \star \\
(38,151)\end{array}$ & $\begin{array}{c}0.010 * \star \star \\
(0.002)\end{array}$ & $\begin{array}{c}0.010 * \star \star \\
(0.002)\end{array}$ & $\begin{array}{c}0.009 * \star \star \\
(0.002)\end{array}$ \\
\hline $\begin{array}{l}\text { Financial controls: } \\
\text { Income } \\
\text { Spousal income and } \\
\text { family wealth }\end{array}$ & & & & & $x$ & $\begin{array}{l}X \\
X\end{array}$ \\
\hline Individuals & & & 75,266 & & & \\
\hline
\end{tabular}

Note: *** indicates significance at the 1 percent level, ${ }^{* *}$ significance at the 5 percent level, and $*$ significance at the 10 percent level. Income is measured as the average real income between 1997 and 2001 (2001 prices in SEK), and wealth is measured in 2001. The outcome is an indicator for receiving full disability pension in 2011. "SFE" is shorthand for "sibling fixed effects". The sample is restricted to individuals not on disability pension between 1997 and 2001. In models "with further controls”, we control for level of education, type of occupation, and marital status. All regressions control for birth year fixed effects, birth order fixed effects and fixed effects for the number of times the individual has been asked whether she smokes. Standard errors are clustered at the mother level. 